\title{
The impact of middle management commitment on improvement initiatives in public organisations
}

\author{
Abdullah Alhaqbani*, PhD candidate \\ (abdullah.alhaqbani@myport.ac.uk) \\ Dr Deborah M. Reed, Principal Lecturer \\ Dr Barbara M Savage, Senior Lecturer \\ Dr Jana Ries, Senior Lecturer \\ Department of Operations and Systems Management, \\ Portsmouth Business School, University of Portsmouth \\ Richmond Building, Portland Street, Portsmouth POI 3DE, UK
}

\begin{abstract}
Purpose: Top management commitment is considered a significant factor in improvement programmes, and many papers have been written about the role of top management commitment in implementing a quality management system. However, not considering other management levels' commitment, such as middle management, may lead to issues in achieving organisational development. Public organisations that work through vertical structures may face a lack of middle management commitment, which might have a negative impact on lower and non-management staff commitment to improvement programmes. In this regard, this study seeks to examine the impact of middle management's commitment towards improvement initiatives in public organisations.

Methodology: Empirical research with a mixed-method design used semi-structured interviews and a questionnaire to explore the current practices of continuous improvement (CI) and examine employees' views from different management levels of the implications of current improvements in a Saudi public service organisation.
\end{abstract}

Findings: The analysis indicated that the lower managers and non-management staff agree that, after the implementation of the quality management system, the organisation's middle management showed a lack of commitment to that system. Moreover, this lack of commitment is recognised in the analysis of participants' views of CI practices recorded in the questionnaire and interviews. This lack of commitment has caused poor employee commitment and thus a lack of problem solving in organisational departments. It is also responsible for a lack of employee involvement, the centralisation of decisions, deficiencies in terms of determining and applying training, inequality between employees and a lack of trust between employees and their managers. These issues could be managed and resolved through middle management and their commitment.

Practical implications: Increasing middle managers' awareness of the importance of their commitment to improvement initiatives can have an impact on employees' commitment towards improvement initiatives, especially in those public organisations that have vertical/hierarchical structures. The level of commitment towards the implementation of improvement programmes needs further in-depth analyses to identify which factors influence public organisation leaders' commitment to improvement programmes.

Value: The results of this study could motivate middle managers in public organisations to review their policies and to facilitate $\mathrm{CI}$ initiatives.

Keywords: Middle management commitment, Quality management, Organisational structure Paper Type: Research paper 


\section{Introduction}

Over the past 35 years, the public sectors of both developing and developed nations have begun to adopt many management techniques from the private sector to improve their performance. Many public services, including healthcare agencies, security, education and other government services, have integrated the notion of quality management into their daily operations to enhance performance and service quality (Saint Martin, 2001, p. 118) as governments across the globe realized the importance of quality in the level of the services they offer to their citizens (Pollitt \& Bouckaert, 2000; Boyne \& Walker, 2002, p. 111). According to Sharma and Hoque (2002, p. 351), quality management caused absenteeism and employee turnover rates to drop as public sector organisations began to work together towards employee and customer satisfaction. Moreover, continuously improving organisational performance is considered to be the base for every successful implementation of quality management (Walsh, Hughes \& Maddox, 2002, p. 300; Temponi, 2005, p. 17).

Fryer, Antony and Douglas (2007) reviewed 29 papers that looked at critical success factors and continuous improvement (CI), and found that $\mathrm{CI}$ is unlikely to succeed if there is a lack of senior management support. Moreover, after reviewing 112 studies in the CI field during the course of this study, these authors determined that the commitment of top management is considered to be among the most critical factors in the success of any efforts that are aimed at changing the operational philosophy of an organisation. Moreover, Kaye and Anderson (1999) and Prajogo and Sohal (2004) claim that leadership and commitment to CI must be demonstrated by managers at all levels of an organisation. Management plays an equally important role after implementation, ensuring a commitment to quality management and working toward success (Grover, Agrawal \& Khan, 2006, p. 449; Sila, 2007, p. 89).

Wooldridge, Schmid and Floyd (2008, p. 1191) state that middle management is a required point of observation from which to study the organisational process associated with building and developing capabilities. Bartlett and Ghoshal (1993, p. 44) confirm the importance of middle managers as horizontal integrators who help to ensure the distribution of knowledgebased resources throughout the organisation. The role of middle management in quality should act as a facilitator to work process, managing employees, enabling change in culture, development and sustainability of quality teams and solving problems (Harrington \& Williams, 2004, p. 302). However, a lack of attention to middle management during the 
improvement process will lead to loopholes or delays in efforts towards organisational development. Zairi, Letza \& Oakland (1994, p. 38) emphasized that a failure associated with TQM implementation is not really the failure of TQM to deliver results but rather a failure of managers' commitment to introduce it effectively. Implementing quality initiatives requires employees to be involved and empowered at their tasks, which might have an adverse impact on the middle management commitment because middle managers see employees' empowerment and involvement as a reduction of their authority and ability to control (Stupak \& Leitner, 2001, p. 17; Harrington \& Williams, 2004, p. 297). Middle management has been seen as a source of resistance to quality improvement processes (Endres, 2000, p. 59; Harrington \& Williams, 2004, p. 303).

Moreover, organisation strategies that lack middle management commitment face serious implementation issues such as unnecessary delays in the strategy implementation process (Floyd \& Wooldridge, 1994, p. 49). Furthermore, lower management commitment toward improvement at public organisations that work through vertical structures might be affected when there is lack of middle-management concern. The commitment of middle managers is crucial to ensure that quality initiatives are implemented effectively at lower levels. Middle managers need to be assured that the strategic goals that they are pursuing are the goals that their actual performance will be measured against (Harrington \& Williams, 2004, p. 304).

Thus, this paper seeks to explore how CI initiatives work in a Saudi Arabian public service organisation and to examine the impact of middle management's commitment towards improvement initiatives. The paper is part of a larger research project that focuses on CI in the Saudi public service sector.

\section{Literature review}

Commitment is critical to successful implementation of CI (Kaye \& Dyason, 1995; Kaye \& Anderson, 1999; Lillrank et al., 2001; Emiliani, 2003; Achanga et al., 2006). The commitment of members of top management is considered to be critical to the success of any efforts that are aimed at changing the operational philosophy of the organisation (Sanjay \& O'Shaughnessy, 1998, p. 16). Moreover, the level of management commitment and support across all management levels may have an impact on success or failure CI efforts at organisation (Oakland, 2011). 
Non-managerial influence also plays an important role in CI implementation (Savolainen, 1999). CI initiatives are dependent on the level of commitment of the participants (Middel, Boer \& Fisscher, 2006), with each participant usually playing one or more roles in improvement process, for example the role of employees in an improvement process can be as facilitators of communication and/or discussion, as information providers and/or as problem solvers.

Bhuiyan and Baghel (2005) have observed that CI initiatives are usually undertaken at three employee levels within an organisation, i.e. at the management level, within teams (both formal and informal) and at the employee level. For the manager, CI initiatives would be more related to concepts of strategy, while for the team level, CI initiatives would probably be involved with initiatives towards resolving issues and challenges within in the improvement processes Finally, on the individual level, CI initiatives would be concerned with everyday, day-to-day tasks so that all tasks are performed more efficiently. It is important that the management takes a strategic view of a CI implementation exercise so that benefits are accrued from all the three levels of activity.

Managers are responsible for creating and maintaining an environment in which employees are fully involved in achieving goals related to CI of organisational performance (Kruger, 2012, p. 170; Parumasur \& Govender, 2013, p. 640). Management commitment to CI is also demonstrated by (a) acceptance of responsibility for successful change resulting from CI, (b) involvement, (c) investment of resources, (d) decisions, (e) understanding of their influence on the behaviour of members of the organisation, (f) empowerment, and ( $g$ ) reviews of progress (Gill, 2002).

The top management of an organisation has the responsibility of supporting the effort of employees to improve processes (Berger, 1997). Moreover, Caffyn (1999) indicated that promoting CI capability within organisations requires managers at all levels to show their active commitment to CI. Evans and Lindsay (2008, p. 461) state that middle management have a critical role in creating and sustaining the culture of CI. The role of middle managers can be more focused on improving operational processes that form the foundation of customer satisfaction, creating a culture of teamwork and cooperation, and preparing employees for changes.

Floyd and Wooldridge (1997, p. 466) emphasised the importance of the role of middle 
managers within organisations, where they facilitate, negotiate, and interpret connections between the strategic and operational levels. Moreover, they suggested a typology of middle management involvement in strategy that describes the upward and downward influence of middle managers on the strategic change process. The typology is composed of two divisions: upward vs downward activity and integrative vs divergent activity, which collectively describe four types of middle-management strategic involvement (Floyd \& Woolridge, 1992, p. 154).

Considering the role of middle management upward, championing alternatives refers to the ability of middle management to provide ideas that have an impact on the organisational future, and synthesizing information is the interpretation and evaluation of information that affects top management (Floyd \& Wooldridge, 1997, p. 467). In the downward direction, towards the lower level of management, facilitating adaptability is the ability of middle managers to promote experimentation and creatively develop work activities. Implementing a deliberate strategy is the ability to recognize implemented objectives and to link organisational activities to the strategic objectives set by top management (Floyd \& Wooldridge, 1992, p. 154; Mantere, 2008, p. 302).

Middle managers require skills to monitor employees and resources involved in implementing organisational plans, the ability to reflect upon their experiences and relationships and to work effectively with employees to implement changes that may arise from the top level of the organization as well as those that may arise from the lower levels of the organisation (Weide \& Wilderom, 2004).

Dale, van der Wiele and van Iwaarden (2007, p. 55) indicated that the role of middle managers will be effective if they are committed to the implementation and development of quality management systems at their organisations. Moreover, they should display behaviours that are supportive of quality management and act as role models for lower level managers and other employees (Evans \& Lindsay, 2008). Furthermore, middle managers should be responsible for explaining quality management principles to employees and ensuring that their own commitment is communicated (Oakland, 2011, p. 519).

Within a quality management context, middle managers should focus on developing the improvement plans and processes of their departments, ensuring that the improvement plans and the department's objectives are compatible with the organisation's strategic objectives. 
Moreover, middle managers need to develop their levels of communication with lower managers and employees, their involvement with the lower level employees and ensure that lower level managers are trained to use improvement tools and techniques. Furthermore, middle managers should work as information providers to top management regarding the quality management implementation process and the difficulties that lower managers and employees face during implementation (Dale et al., 2007, p. 55).

This study examines the role of middle management commitment in facilitating improvement initiatives at public service organisations in Saudi Arabia.

\section{Research Method}

This empirical research is part of a larger research program studying CI in eight organisations within the Saudi Arabian public service sector. A mixed-method design has been employed to collect qualitative and quantitative data. Semi-structured interviews and a questionnaire were conducted to explore the current practices of CI and to examine the views of employees from different management levels on the implications of current improvements in these Saudi Arabian public service organisations. This paper addresses the findings from just one of the investigated organisations.

Two managers from each organisation, who have an in-depth understanding of the current CI practices and issues that organisations face in implementing improvement initiatives, were selected to take part in semi-structured interviews as critical cases (Ritchie \& Lewis, 2003, p. 79; Silverman, 2011, p. 388). The findings from the literature and interviews were then combined to design the 45 items of the research questionnaire. To ascertain participants' views on these CI practices, a 5-point Likert scale was used, where (1) was 'strongly disagree' and (5) was 'strongly agree'. These were supplemented by open questions to provide a richer understanding of the responses to the closed questions.

The questionnaire instrument was pilot tested by 33 participants from two organisations that were not involved in the research to improve the internal validity of research questionnaire.

Moreover, five experts who have experience in the public sector and in the development and improvement of Saudi Arabian government organisations were invited to evaluate survey formatting, clarity, question wording, overlapping responses, and question balancing of the questionnaire. The pilot study suggested that there were some technical alterations necessary to eliminate four items and rephrase two. The final part of the pilot test was to determine the 
internal consistency of questionnaire items using alpha coefficient tests. The reliability test result was 0.86 , which demonstrated that the data measurements were internally consistent.

Factor analysis of the identified CI practices resulted in the description of seven measurement factors: development and learning, communication, strategic performance management, customer focus, process and management support, employees focus, and team problemsolving. The rationale behind selecting factor analysis was that it enables the researcher to generate a group of latent variables underpinning a set of measured variables, thus improving the quality of the research findings by allowing the researcher to identify and eliminate items that fail to fit into any of the factors or that fit into more than one of those factors (Field, 2009; DeVellis, 2012).

\section{Case study research}

MU is one of the Saudi Arabian public service organisations that have recently implemented a quality management system. MU is responsible for designing municipal services that are provided to the public through eleven regional offices which, at the time of the research, had 217 employees working on the development and improvement of the services provided to the public. The organisation has a traditional bureaucratic structure, with vertical management layers that include a top management board, middle management, lower management and non-management staff. In recent years, the advent of information technology has placed immense pressure on the public service sector to adopt a more collaborative and informationsharing environment that can increase organisational efficiency and effectiveness. MU has an established departmental quality management system that focuses on reviewing existing work processes and improving the e-services that are provided to customers through its offices.

Two managers from the MU top management board (the senior manager and the planning and development manager) were selected for interviews. The research questionnaire was distributed to and self-administered by the entire MU population (217 employees), whether management, including upper managers, middle management, lower management or nonmanagement staff. The size of MU was considered to be sufficiently manageable to facilitate the distribution of the questionnaire to all employees including all levels of management (Saunders, Lewis \& Thornhill, 2009, p. 212). To enable a process of confirming the findings of interviews and questionnaire, respondents were asked, via the questionnaire, to volunteer as a self-selecting sample of those who wished to take part in either follow-up semi- 
structured interviews and/or focus groups discussing their perceptions about CI and CSFs in MU (Saunders et al., 2009, p. 241).

A template analysis was carried out on the qualitative data that was collected through semistructured interviews and on the open questions within the questionnaire. A template analysis refers to a list of codes representing factors or themes, identified within a text (Saunders et al., 2009, p. 489) that can be used to consolidate different participants' perspectives into one context, which is considered a more flexible technique with less complex procedures (King, 2004, p. 257).

The questionnaire data was analyzed using descriptive analysis including the frequency of participants' distribution, mean values of questionnaire items and the overall mean value of key improvement factors in order to assess participants' agreement and disagreement toward the questionnaire items and factors. Moreover, one-way ANOVA was used to establish whether the means of factors differed across participants' job levels (Hamilton, 2008, p.163). In the following section, the response of interviewees and the questionnaires are discussed.

\section{Results and discussion}

The response rate for the questionnaire was 149 of 217 , or $69 \%$ and 52 participants of the 149 took the opportunity to offer additional comments to supplement their responses to the closed questions. Table 1 presents the percentage of respondents according to their positions.

\begin{tabular}{lc} 
Management level & $\begin{array}{c}\text { Percent of } \\
\text { respondents }\end{array}$ \\
\hline Upper management & 1.3 \\
Middle management & 13.4 \\
Lower management & 24.8 \\
Non-management staff & 56.5 \\
Not stated & 4 \\
\hline
\end{tabular}

Table 1: Questionnaire responses by employees' positions

Considering the role of senior managers in relation to CI, both of the interviewed managers agreed that their role could be fulfilled through their commitment to improving organisational performance, meeting organisational objectives and implementing organisational plans. Moreover, improving services that are provided to customers is considered one of the MU's main targets. The organisation's senior manager stated that continuously achieving customer satisfaction is one of the biggest challenges facing MU management and "[once] customers' 
complaints disappear from our organisation then we know that we are on the right way to achieve the strategic objectives".

Furthermore, MU senior managers indicated that the benefits of the established quality management approach at the organisation are the increasing awareness of the services that are provided to customers, improved external communication with customers and other public organisations and simplified work processes. However, the development manager stated that when the organisation started applying a quality management system and transferred employees' work partly to new lines of electronic work processes, there were some departments that did not accept these changes easily. This might relate to the work characteristics in these departments, the level of employee and manager response to changes in the organisation and/or the lack of sufficient awareness about quality.

Moreover, the interviewees stated that the quality management system presented some issues that may impact on quality management sustainability in the future. One of the major issues that the organisation faces is employees' resistance to change, which is caused in the interviewees' view, by a lack of commitment and motivation. Furthermore, both senior managers reported that there was a lack of commitment on the part of middle management to the current improvement efforts.

Using the responses to the questionnaire, descriptive statistical analysis was used to reveal various improvement factors, including development and learning, the level of communication and cooperation, strategic performance management, internal and external customer focus, process management support, employee focus and team problem-solving.

This analysis of the measurement factors (Table 2) indicates generally that, statistically, participants were neutral towards the current CI practices at MU.

\begin{tabular}{lc}
\hline \multicolumn{1}{c}{ Key factors } & Mean \\
\hline Development and learning & 3.44 \\
Communication & 3.24 \\
Strategic performance management & 3.40 \\
Customer focus & 3.43 \\
Process and management support & 3.58 \\
Employees focus & 3.28 \\
Team problem solving & 2.64 \\
\hline
\end{tabular}

Table 2: Key factors of CI practices 
However, the mean value of 3.58 for the process management factor is the exception and indicates that participants tend to agree that incremental changes in work processes contribute to making improvements in organisational processes and enhance the cooperation between departments and the sharing experience between employees.

Furthermore, maintaining a commitment by top management to providing all resources necessary, and involvement at the lower level of the organisation, contributes to improving work processes. The level of improvement in these work processes may result from the establishment of quality management at the organisation.

The descriptive analysis of key factors indicated that participants tend to agree with six improvement practices (Table 3).

\begin{tabular}{|c|c|c|c|}
\hline \multirow{2}{*}{ Improvement practices } & \multirow{2}{*}{ Mean } & \multicolumn{2}{|c|}{$\begin{array}{l}95 \% \text { confidence } \\
\text { interval for Mean }\end{array}$} \\
\hline & & $\begin{array}{l}\text { Lower } \\
\text { Bound }\end{array}$ & $\begin{array}{l}\text { Upper } \\
\text { Bound }\end{array}$ \\
\hline $\begin{array}{l}\text { Availability of training courses to } \\
\text { employees. }\end{array}$ & 3.58 & 3.41 & 3.74 \\
\hline $\begin{array}{l}\text { Considering employees as internal } \\
\text { customers. }\end{array}$ & 3.91 & 3.77 & 4.05 \\
\hline $\begin{array}{l}\text { Employees can seek out opportunities } \\
\text { for learning and personal development. }\end{array}$ & 3.62 & 3.47 & 3.78 \\
\hline Identifying external customers' needs. & 3.52 & 3.36 & 3.67 \\
\hline $\begin{array}{l}\text { Organisational information is timely in } \\
\text { how it flows into organisational } \\
\text { departments. }\end{array}$ & 3.68 & 3.52 & 3.83 \\
\hline $\begin{array}{l}\text { The organisation's aims and objectives } \\
\text { are clearly identified. }\end{array}$ & 3.65 & 3.49 & 3.81 \\
\hline
\end{tabular}

Table 3: Improvement practices as stated by participants

However, the analysis indicated some disagreement regarding team problem-solving among lower management and non-management staff participants. The issues included the lack of a specialist in the problem-solving team, such as a process design specialist or IT specialist, the lack of an analytical approach, and the lack of cooperation across boundaries at all levels.

To determine whether there are any statistically significant differences between the means of participant groups, a one-way analysis of variance (ANOVA) was used to establish whether the means of the factors differed across participants' job levels (Hamilton, 2008, p. 163).

However, there are assumptions that need to be considered before running one-way ANOVA. These assumptions include that testing that the dependent variable is normally distributed for each group of independent variables and a test of the homogeneity of variances (Levene's test was used here) to determine if the population variance for each group is the same (LarsonHall, 2010, p. 272). The analysis indicated that the quantitative data is normally distributed, 
however the assumption of homogeneity of variances was violated (Equal Variances Not Assumed), the $\mathrm{p}$ value is less than significant at the 0.05 level for the communication factor. This result suggests using the Welch test for correction and promoting ANOVA. However, the Welch test indicated that there were significant differences between participants' groups across management levels and the Games-Howell post hoc test was used to determine exactly where the differences lay.

The mean value of the measurement factors showed that while middle managers agree with the CI practices at MU, lower-management and non-management-staff participants were either neutral or disagreed with development and learning support activities at MU, the level of communication, strategic performance management, employees focus and team problemsolving factors. These findings indicated some conflicts between middle management views and other management level views regarding improvement in the organisation.

The analysis of differences between MU participants' responses in terms of their job levels confirm that the p-values for development and learning support, communication, customer focus, process management support and team problem solving are less than the significance level of 0.05 , which indicates that, statistically, there are significant differences between participants' responses regarding these factors (Table 4).

\begin{tabular}{llrrrrr}
\hline \multirow{2}{*}{ Key improvement factors } & $\begin{array}{c}\text { Sum of } \\
\text { Squares }\end{array}$ & df & $\begin{array}{c}\text { Mean } \\
\text { Square }\end{array}$ & F & Sig. \\
\hline \multirow{2}{*}{$\begin{array}{l}\text { Development and } \\
\text { learning }\end{array}$} & Between Groups & 5.343 & 4 & 1.336 & 2.505 & $.045^{*}$ \\
& Within Groups & 76.770 & 144 & .533 & & \\
& Total & 82.113 & 148 & & & \\
\hline \multirow{5}{*}{ Communication } & Between Groups & 14.955 & 4 & 3.739 & 4.251 & $.003^{*}$ \\
& Within Groups & 126.632 & 144 & .879 & & \\
\hline \multirow{5}{*}{ Customer focus } & Total & 141.587 & 148 & & & \\
\hline \multirow{2}{*}{$\begin{array}{l}\text { Process management } \\
\text { support }\end{array}$} & Between Groups & 5.179 & 4 & 1.295 & 2.525 & $.043^{*}$ \\
& Within Groups & 73.826 & 144 & .513 & & \\
& Total & 79.006 & 148 & & & \\
\hline \multirow{2}{*}{ Team problem solving } & Within Groups & 58.626 & 144 & .407 & & \\
& Total & 63.922 & 148 & & & \\
\hline & Between Groups & 7.589 & 4 & 1.897 & 2.770 & $.030^{*}$ \\
& Within Groups & 98.619 & 144 & .685 & & \\
\hline
\end{tabular}

Table 4: ANOVA test of key factors. 
The comparison between participants' groups showed that the views of middle-management participants are significantly different from non-management staff participants in relation to factors including development and learning, communication, customer focus, process management support, and team problem-solving (Table 5).

\begin{tabular}{|c|c|c|c|c|c|c|c|}
\hline \multirow[t]{2}{*}{ Dependent Variable } & \multirow{2}{*}{$\begin{array}{c}\text { (I) } \\
\text { Management } \\
\text { Level }\end{array}$} & \multirow{2}{*}{$\begin{array}{c}(\mathbf{J}) \\
\text { Management } \\
\text { Levels }\end{array}$} & \multirow{2}{*}{$\begin{array}{c}\text { Mean } \\
\text { Difference } \\
\text { (I-J) }\end{array}$} & \multirow{2}{*}{$\begin{array}{l}\text { Std. } \\
\text { Error }\end{array}$} & \multirow[t]{2}{*}{ Sig. } & \multicolumn{2}{|c|}{ 95\% Confidence Interva } \\
\hline & & & & & & $\begin{array}{l}\text { Lower } \\
\text { Bound }\end{array}$ & $\begin{array}{l}\text { Upper } \\
\text { Bound }\end{array}$ \\
\hline \multirow{4}{*}{$\begin{array}{l}\text { Development and } \\
\text { learning }\end{array}$} & \multirow{4}{*}{$\begin{array}{l}\text { Middle } \\
\text { management }\end{array}$} & Upper management & -.047 & .541 & .930 & -1.12 & 1.02 \\
\hline & & Lower management & .358 & .203 & .080 & -.04 & .76 \\
\hline & & Non-management staff & $.466^{*}$ & .182 & .011 & .11 & .83 \\
\hline & & Not stated & $.872^{*}$ & .340 & .011 & .20 & 1.54 \\
\hline \multirow{4}{*}{ Communication } & \multirow{4}{*}{$\begin{array}{l}\text { Middle } \\
\text { management }\end{array}$} & Upper management & -.208 & .695 & .765 & -1.58 & 1.17 \\
\hline & & Lower management & .262 & .260 & .315 & -.25 & .78 \\
\hline & & Non-management staff & $.603^{*}$ & .233 & .011 & .14 & 1.06 \\
\hline & & Not stated & $1.514^{*}$ & .437 & .001 & .65 & 2.38 \\
\hline \multirow{4}{*}{ Customer focus } & \multirow{4}{*}{$\begin{array}{l}\text { Middle } \\
\text { management }\end{array}$} & Upper management & -.250 & .531 & .638 & -1.30 & .80 \\
\hline & & Lower management & .191 & .199 & .337 & -.20 & .58 \\
\hline & & Non-management staff & $.442^{*}$ & .178 & .014 & .09 & .79 \\
\hline & & Not stated & .639 & .333 & .057 & -.02 & 1.30 \\
\hline \multirow{4}{*}{$\begin{array}{l}\text { Process management } \\
\text { support }\end{array}$} & \multirow{4}{*}{$\begin{array}{l}\text { Middle } \\
\text { management }\end{array}$} & Upper management & -.142 & .473 & .765 & -1.08 & .79 \\
\hline & & Lower management & .156 & .177 & .381 & -.19 & .51 \\
\hline & & Non-management staff & $.364^{*}$ & .159 & .023 & .05 & .68 \\
\hline & & Not stated & $.886^{*}$ & .297 & .003 & .30 & 1.47 \\
\hline \multirow{4}{*}{ Team problem solving } & \multirow{4}{*}{$\begin{array}{l}\text { Middle } \\
\text { management }\end{array}$} & Upper management & .350 & .614 & .569 & -.86 & 1.56 \\
\hline & & Lower management & $.535^{*}$ & .230 & .021 & .08 & .99 \\
\hline & & Non-management staff & $.671^{*}$ & .206 & .001 & .26 & 1.08 \\
\hline & & Not stated & .739 & .385 & .057 & -.02 & 1.50 \\
\hline
\end{tabular}

Table 5: Comparison of mean differences between participants groups.

Moreover, the analysis showed that there is a division of participants' views to evaluate the priority of the improvement teams in problem-solving at MU. The analysis indicated that middle management participants agree to the role of teams in problem-solving and improving operational processes. However, the views of lower management and non-management participants showed that controlling the cooperation with improvement teams to address improvement issues and implement required changes at management levels, lack of using appropriate methods to improve processes and lack of specialists in these teams affected the role of improvement teams at MU. The results of the statistical analysis indicate that there is a gap between views of middle managers and other participants regarding improvement practices at MU. Furthermore, these results are supported by the views of participants in focus group and interviews.

In the second part of the questionnaire, 52 of the 149 respondents from middle management, 
lower management and non-management staff responded to the open questions regarding current CI practices at MU. The participants indicated that the structure of the organisation plays an important role in implementing a strategy. Although MU has a vertical structure, as a result of public-sector bureaucracy and the centralisation of decision-making, participants emphasized the role of middle management in the organisation. Moreover, lower management and non-management staff indicated that middle management at MU plays as important a role as top management but lacks top management's commitment, which caused delay in improving organisation activities. In an organisation with a hierarchical structure such as MU's, middle management extends from the managers located below the top managers to those immediately above the first-level supervisors (Dutton \& Ashford, 1993). The structural position of middle managers should allow them to work as channels for the translation of top management strategic objectives as well as an important force for managing organisation activities (Salih \& Doll, 2013).

Although, in theory, the role of middle management is to facilitate and implement the change process in a downward direction, the survey responses from lower levels reported a lack of middle management commitment after implementation of the quality management system. Moreover, this issue was also reported by senior managers during the interviews. Statistically, the analysis showed that there are significant differences between the views of lower level management and middle management. Furthermore, lower management and nonmanagement staff participants indicated that their lack of commitment to ongoing improvement in the organisation is a result of a lack of commitment from middle management. Many issues were reported by lower level participants after implementation of the quality management system, vis-a- vis:

- Lack of problems solving processes in organisational departments.

- Lack of employee involvement in improvement processes.

- Centralisation of decisions that caused lack of empowerment.

- Lack of communication between departments due to centralisation at organisation.

- Deficiencies in terms of determining and applying training that focus on improvement

- Lack of trust between employees and managers.

- Inequality between employees and workloads in some departments.

- Lack of updating work process due to the lack of empowerment.

- Lack of integrated improvement processes within departments' operation plans. 
The system of MU seems to be similar to the organisations that implement a managing by objectives (MBO) approach. This approach is used by managers to link the targets of the organisation system with employees' goals and behaviours. MBO focuses on the results rather than the organisation system, controlling employees rather than processes and lacking cooperation in the organisation. These features of MBO may not be compatible with quality behaviours and might lead to the failure of the quality programme (Castellano \& Roehm, 2001, p. 40). Moreover, CI issues that were identified at MU indicated that the impact of MBO still exists after implementing quality initiatives which might influence the commitment of middle management to quality at lower levels creating a resistance to changes that quality processes required. However, it is noted that the influence of MBO on quality initiatives is debatable among scholars (Berg, 1995, p.130; Castellano \& Roehm, 2001, p. 39; Stupak \& Leitner, 2001, p. 752). Improvement initiatives require organisation management to focus on improving the system that causes results, implementing suitable methods for improvement and cooperation among management levels.

The research findings were discussed with eight MU employees who had agreed to participate in a follow-up focus group and/or interview. Six participants of middle and lower management levels were involved in a focus group and two members of non-management staff participated in a semi-structured interview. Focus group participants confirmed the issues found at MU and indicated that although the relationship between management levels seems to be acceptable, there is a communication gap and lack of cooperation between management levels. Moreover, the impacts of centralisation at MU after implementation of quality management still exist at middle management level. In the interviews, one participant indicated that the "organisation without restructuring their management levels will face difficulties in improving its communication". Another issue indicated in the focus group and interviews is that middle managers hold their positions for a long time and this contributes to the lack of commitment to changes that affect their authority. Managers' turnover at the middle level will contribute to overcoming centralisation and the communication gap at this level and during the implementation of improvement programmes. Moreover, MU requires the replacements to be young and qualified leaders to implement changes and drive performance. The results suggested that commitment of middle management in improvement processes is considered a central feature of quality initiatives and lack of this role will hinder the quality efforts. 
Lam (1996) stated that middle managers are more resistant to the implementation of quality management, which may require changes in managerial style and the nature of middle managers' work. Middle managers received more changes in their job role to implement quality management. These changes include working relationships with employees, job responsibility, increased workload and participation in decision-making process (Lam 1996, p. 41). However, these changes may impact on the middle managers' role if there is a lack of their commitment. Furthermore, Schuler and Harris (1992, cited in Dale et al., 2007, p. 209) stated that middle management should pay more attention to quality management and that their lack of involvement in quality system design and training will lead to them becoming resistant to the change process.

In public organisations with a vertical structure, such as MU, middle management and top management seems to be much closer than the middle management and lower levels. Wooldridge, Schmid and Floyd (2008, p.1192) state that middle managers have more access to top management level as well as their knowledge of operational levels. So, they have a vital role in implementing the organisation's strategy and improving organisational activities. Moreover, Howell and Higgins (1990) and Mantere (2008, p. 311) found that top management commitment to middle managers increased the authority of those middle managers to define departmental goals and to facilitate adaptability and implement a deliberate strategy.

The issues that were identified in this research by lower level participants can be considered as the factors that are required for successful middle management commitment. These factors include team problem-solving, involvement, increasing the level of trust through empowerment and decentralisation of decisions, communication between organisational departments, the availability of training and learning for employees and allowing employees to apply the outcomes of training programmes and the integration of CI with departmental plans.

In addition to the issues reported by participants, this study suggests that perhaps there are possible issues that cause a lack of commitment at the middle management level, such as their poor understanding of the purpose of quality management and of the meaning of commitment, a lack of sufficient awareness about quality benefits, their limited authority 
within the organisation, a lack of training and management turnover during quality management implementation. These issues need to be considered in further research.

\section{Conclusions}

The research reported here examined the impact of middle management in a public service organisation on improvement initiatives. There is no doubt that top management's commitment is considered a significant factor in improvement efforts and programmes. However, commitment on the part of other management levels is also crucial. Although implementing quality management at a public service organisation improved work processes and customer service, a lack of middle management commitment after the establishment of improvement practices caused a lack of employee commitment within the vertical structure. Thus, the level of commitment on the part of middle management will have an impact on lower levels of management. The issues that were identified by the participants could be resolved if middle management became committed to improvement initiatives.

The issues with middle management commitment identified in this study were found after the implementation of quality management and therefore suggest that middle managers need to be trained to accept the changes in their traditional job role that result from implementation improvement initiatives. Moreover, further research should examine the role of middle management before the implementation of improvement initiatives and consider possible issues to maintain middle management's commitment to CI. Furthermore, the current study suggested possible issues that cause a lack of middle management commitment. The impact of these issues could be examined in further work and in a different context.

\section{References}

Achanga, P., Esam S., Rajkumar,R. \& Geoff, N. (2006). Critical Success Factors for Lean Implementation within SMEs, Journal of Manufacturing Technology Management, 17 (4), 460-471.doi: 10.1108/17410380610662889

Bartlett, C. A., \& Ghoshal, S. (1993). Beyond the M- form: Toward a managerial theory of the firm. Strategic Management Journal, 14(S2), 23-46.doi: 10.1002/smj.4250141005

Berg, A.M. (1995). Public sector quality a pragmatic approach. In, A. Halachmi, \& G. Bouckaert (Eds.), Public productivity through quality and strategic management (pp.127-136), Amsterdam: IOS Press. 
Berger, A. (1997). Continuous improvement and standardization and organizational designs. Integrated Manufacturing Systems, 8(2), 110-117. doi:10.1108/09576069710165792

Bhuiyan, N., \& Baghel, A. (2005). An overview of continuous improvement: from the past to the present. Management Decision, 43 (5), 761-771. doi:10.1108/00251740510597761

Boyne, G. A., \& Walker, R.M. (2002) Total Quality Management and Performance: An Evaluation of the Evidence and Lessons for Research on Public Organizations. Public Performance \& Management Review, 26(2), 111-131. Retrieved from http://www.jstor.org/discover/10.2307/3381273?uid=2129\&uid=2\&uid=70\&uid=4\&si $\mathrm{d}=21104518632413$

Caffyn, S. (1999). Development of a continuous improvement self-assessment tool. International Journal of Operations \& Production Management, 19 (11), 1138-1153. doi:10.1108/01443579910291050

Castellano, J. F., \& Roehm, H.A. (2001). The problems with managing by objectives and results. Quality Progress, 34 (3), 39 - 46. Retrieved from http://asq.org/qic/displayitem/?item $=14486$

Dale, B., G., van der Wiele, T., \& van Iwaarden, J. (Eds.). (2007) Managing Quality, Oxford: Blackwell.

DeVellis, R.F. (2012). Scale Development: Theory and Applications, London: SAGE Publications Ltd.

Dutton, J. E., \& Ashford, S. J. (1993). Selling issues to top management. Academy of Management Review, 18(3), 397- 428. Retrieved from

http://webuser.bus.umich.edu/janedut/Issue\%20Selling/sellingissues.pdf

Emiliani, M. L. (2003). Linking leaders' beliefs to their behaviors and competencies. Management Decision, 41(9), 893-910.doi: 10.1108/00251740310497430

Endres, A.(2000). Implementing Juran's Road Map for Quality Leadership: Benchmarks and Results, New York: John Wiley \& Sons, Inc.

Evans, J., \& Lindsay, W. (2008). Managing for Quality and Performance Excellence. Mason: Thomson South-Western.

Field. A. (2009). Discovering Statistics Using SPSS. London: SAGE Publications Ltd.

Floyd, S. W., \& Wooldridge, B. (1992). Middle management involvement in strategy and its association with strategic type: A research note. Strategic Management Journal, 13(S1), 153-167. doi: 10.1002/smj.4250131012

Floyd, S.W., \& Wooldridge, B. (1994). Dinosaurs or Dynamos? Recognizing Middle Management's Strategic Role. Academy of Management Executive, 8(4), 47-57.doi: 10.5465/AME.1994.9412071702

Floyd, S. W., \& Wooldridge, B. (1997). Middle management's strategic influence and 
organizational performance. Journal of Management Studies, 34(3), 465-485.

doi: 10.1111/1467-6486.00059

Fryer, K. J., Antony, J., \& Douglas, A. (2007). Critical success factors of continuous improvement in the public sector: A literature review and some key findings. The TQM Magazine, 19(5), 497-517. doi:10.1108/09544780710817900

Gill, R. (2002). Change management or change leadership? Journal of Change Management, 3(4), 307-318. doi: 10.1080/714023845

Grover, S., Agrawal, V., \& Khan, I. (2006). Role of human factors in TQM: a graph theoretic approach. Benchmarking: An International Journal, 13(4), 447- 468. doi: http://dx.doi.org/10.1108/14635770610676290

Hamilton, L.C. (2008). Statistic with STATA, Belmont: Brooks/Cole,

Harrington, D., \& Williams, B. ( 2004). Moving the quality effort forward - the emerging role of the middle manager. Managing Service Quality, 14 (4), 297-306. doi: $10.1108 / 09604520410546833$

Howell, J. M. \& Higgins, C. A. (1990). Champions of technological innovation. Administrative Science Quarterly, 35(2), 317-341. Retrieved from http://www.jstor.org/stable/2393393

Kaye, M. M., \&, Dyason, M.D.(1995). The fifth era. The TQM Magazine, 7(1), 33-37.doi: $10.1108 / 09544789510076898$

Kaye, M., \& Anderson, R. (1999). Continuous improvement: the ten essential criteria. International Journal of Quality \& Reliability Management, 16(5), 485-509. doi: 10.1108/02656719910249801

King, N. (2004). Using templates in the thematic analysis of text. In C. Cassell, \& G. Symon (Eds.), Essential Guide to Qualitative Methods in Organizational Research (pp. 256 270). London: SAGE Publications Ltd.

Kruger, M. (2012). Leading quality management for improved public service delivery. African Journal of Public Affairs, 5(3), 167-178. Retrieved from http://repository.up.ac.za/bitstream/handle/2263/31725/Kruger_Leading (2012).pdf?sequence $=1$

Lam, S. S. (1996). Total quality management and its impact on middle managers and frontline workers. Journal of Management Development, 15(7), 37- 46. doi: $10.1108 / 02621719610122794$

Larson-Hall, J. (2010). A guide to doing statistics in second language research using SPSS. Abingdon: Routledge. 
Lillrank, P., Shani, A. B., \& Lindberg, P. (2001). Continuous improvement: Exploring alternative organizational designs. Total Quality Management, 12(1), 41-55. doi:10.1080/09544120020010084

Mantere, S. (2008). Role Expectations and Middle Manager Strategic Agency. Journal of Management Studies, 45: 294 -316. doi: 10.1111/j.1467-6486.2007.00744.x

Middel, R., Boer, H., \& Fisscher, O. (2006). Continuous improvement and collaborative improvement: similarities and differences. Creativity and Innovation Management, 15(4), 338-347. doi:10.1111/j.1467-8691.2006.00407.x

Oakland, J. (2011). Leadership and policy deployment: The backbone of TQM. Total Quality Management and Business Excellence, 22(5), 517-534, doi:10.1080/14783363.2011.579407

Parumasur, S.B., \& Govender, P. (2013). The importance of teamwork, continuous top management support and training in bringing about TQM. Journal of Economics and Behavioral Studies, 5(9), 639-651. Retrieved from http://www.ifrnd.org/Research\%20Papers/J5(9)7.pdf

Pollitt, C., \& Bouckaert, G. (2000). Public Management Reform: A Comparative Analysis. $\left(2^{\text {nd }}\right.$ ed). Oxford: Oxford University Press

Prajogo, D.I., \& Sohal, A.S. (2004). The sustainability and evolution of quality improvement programmes - an Australian case study. Total Quality Management \& Business Excellence, 15 (2), 205-220. doi: 10.1080/1478336032000149036

Ritchie, J., \& Lewis, J. (Eds.). (2003). Qualitative Research Practice: A Guide for Social Science Students and Researchers. London: SAGE Publications Ltd.

Saint Martin, D. (2001). When industrial policy shapes public sector reform: Total quality management in Britain and France. West European Politics, 24(4), 105 - 124. doi: $10.1080 / 01402380108425467$

Salih, A., \& Doll, Y. (2013). A middle management perspective on strategy implementation. International Journal of Business and Management, 8(22), 32-39. doi: http://dx.doi.org/10.5539/ijbm.v8n22p32

Sanjay L. A. \&. O’Shaughnessy, K.C. (1998). The role of top management commitment in quality management: an empirical analysis of the auto parts industry, International Journal of Quality Science, 3(1), 5 - 37. doi: 10.1108/13598539810196868

Saunders, M., Lewis, P., \& Thornhill, A. (2009). Research Methods for Business Students $\left(5^{\text {th }}\right.$ ed). Harlow: Pearson Education Limited.

Savolainen, T. I. (1999). Cycles of continuous improvement: Realizing competitive advantages through quality. International Journal of Operations \& Production Management, 19(11), 1203-1222. doi:10.1108/01443579910291096 
Sharma, U., \& Hoque, Z. (2002). TQM implementation in a public sector entity in Fiji. International Journal of Public Sector Management, 15(5), 340-360.doi: 10.1108/09513550210435700

Sila, I. (2007). Examining the effects of contextual factors on TQM and performance through the lens of organizational theory: an empirical study. Journal of Operations Management, 25(1), 83-109. Retrieved from http://www.sciencedirect.com/science/article/pii/S0272696306000064

Silverman, D. (2011). Interpreting Qualitative Data. London: SAGE Publications Ltd.

Stupak, R. J., \& Leitner, P. M. (Eds.). (2001). Handbook of Public Quality Management. New York: Marcel Dekker, Inc.

Temponi, C. (2005). Continuous improvement framework: implications for academia. Quality Assurance in Education, 13(1), 17-36. doi:10.1108/09684880510578632

Walsh, A., Hughes, H., \&. Maddox, D. (2002). Total quality management continuous improvement: is the philosophy a reality?. Journal of European Industrial Training, 26(6), 299-307. doi: 10.1108/03090590210431274

Weide, J.G.V., \& Wilderom, C.P.M. (2004). Deromancing leadership: what are the behaviours of highly effective middle managers?. International Journal of Management Practice, 1 (1), 3-20. doi: 10.1504/IJMP.2004.004867

Wooldridge, B., Schmid, T., \& Floyd, S. W. (2008). The middle management perspective on strategy process: contributions, synthesis, and future research. Journal of Management, 34 (6), 1190-1221. doi: 0.1177/0149206308324326

Zairi, M., Letza, S. R., \& Oakland, J. S. (1994). Does TQM impact on bottom-line results?. The TQM Magazine, 6 (1), 38 - 43.doi: 10.1108/09544789410052750 